\title{
Effect of Hyporheic Exchange on Macroinvertebrate Community in the Weihe River Basin, China
}

\author{
Qidong Lin ${ }^{1,2}$, Jinxi Song ${ }^{1,2,3, *}$, , Carlo Gualtieri ${ }^{4}{ }^{-}$, Dandong Cheng ${ }^{1,2}$, Ping Su ${ }^{1,2}$, \\ Xinxin Wang ${ }^{1,2}$, Jiaxu Fu ${ }^{1,2}$ and Jianglin Peng ${ }^{1,2}$ \\ 1 Shaanxi Key Laboratory of Earth Surface System and Environmental Carrying Capacity, \\ College of Urban and Environmental Sciences, Northwest University, Xi'an 710127, China; \\ qidonglin@stumail.nwu.edu.cn (Q.L.); chengdandong@hotmail.com (D.C.); \\ pingsu@stumail.nwu.edu.cn (P.S.); xinxinwang@stumail.nwu.edu.cn (X.W.); \\ jiaxufu@stumail.nwu.edu.cn (J.F.); jianglinpeng@stumail.nwu.edu.cn (J.P.) \\ 2 Institute of Qinling Mountains, Northwest University, Xi'an 710127, China \\ 3 State Key Laboratory of Soil Erosion and Dryland Framing on the Loess Plateau, Institute of Soil and Water \\ Conservation, Chinese Academy of Sciences, Yangling 712100, China \\ 4 Department of Civil, Architectural and Environmental Engineering (DICEA), University of Napoli “Federico \\ II", Napoli 80125, Italy; carlo.gualtieri@unina.it \\ * Correspondence: jinxisong@nwu.edu.cn; Tel.: +86-29-8830-8596
}

Received: 30 December 2019; Accepted: 6 February 2020; Published: 8 February 2020

check for updates

\begin{abstract}
The effect of hyporheic exchange on macroinvertebrates is a significant topic in ecohydraulics. A field study was conducted during May and June 2017 to investigate the impacts of magnitude and patterns of hyporheic exchange on the sediment macroinvertebrate community in the Weihe River basin. The results demonstrate that upwelling flows cause resuspension of riverbed sediment, increasing the proportion of swimmer groups (such as Baetidae) in the macroinvertebrate community. However, large resuspension of river bed sediment results in a reduced abundance of macroinvertebrates. By controlling the transport processes of dissolved oxygen (DO), dissolved organic carbon (DOC), nutrients, temperature, and different patterns of hyporheic exchange strongly influence the structure of macroinvertebrate communities. Downwelling is more likely to produce rich invertebrate communities than upwelling. The magnitude for the hyporheic flux of 150-200 mm/d was optimal for the macroinvertebrate community in the Weihe River Basin. Above or below this rate results in a decline in community abundance and diversity. We suggest that research is conducted to better understand the effects of hyporheic exchange across bedforms on macroinvertebrate communities. The study supports any activities to preserve the ecological functions and health of rivers dominated by fine-grained sediments.
\end{abstract}

Keywords: Ecohydraulics; hyporheic exchange; macroinvertebrate community; resuspension

\section{Introduction}

Macroinvertebrates are an important biological part of the river system and they are used as indicators of ecosystem integrity and productivity [1-3]. Thus, investigation of the macroinvertebrate community response to aquatic ecosystems has been a hotspot [4]. The hyporheic zone (HZ), which is the volume of riverbed sediments where surface water (SW) and groundwater (GW) are mixing $[5,6]$, is a storage zone in river ecosystems for transported and released solutes $[1,7,8]$. Many ecological processes are related to hyporheic exchange, because this affects the substrate properties and water quality and produces physicochemical gradients to which macroinvertebrates are sensitive $[9,10]$. Therefore, hyporheic exchange not only provides key ecological processes [11], but more importantly affects the development of macroinvertebrate communities in river ecosystems [10,12]. Actually, 
hydrology, ecology, and organisms were jointly applied to assess the dynamic interactions among them [13-16]. Thus, the significance of hyporheic exchange in linking macroinvertebrates has emerged as a relevant component of riverine ecosystem conservation and human sustainable development $[9,17]$.

Previous studies have shown that surface water-groundwater exchange can stimulate the turnover of dissolved organic carbon (DOC) from terrestrial ecosystems or surface river backflowing $[5,18]$. However, organic matter and oxygen are important electron donors and acceptors for biological respiration processes, and their concentration can limit the distribution of macroinvertebrates [18,19]. It has been also confirmed that nutrients, such as dissolved inorganic nitrogen, and temperature dynamics of surface water (SW) or groundwater (GW), which control water chemistry processes, are strongly regulated by exchange fluxes [20,21]. Nitrogen nutrients are converted into essential substances, such as organic nitrogen (nucleic acids, proteins), through biological activities [22]. However, excessive nutrient loading leads to large modifications in the biodiversity of macroinvertebrate communities [23]. The life and assemblage of macroinvertebrates are strongly associated with river thermal regimes, and extreme temperatures reduce the productivity of the community [20,24]. Additionally, hyporheic exchange has significant implications for the resuspension/deposition processes of fine organic particulates in bed sediment, which alter ecosystem properties [25-30]. Deposited sediment could be swept away when the magnitude of hyporheic exchange increases [31]. Actually, the physical properties of sediment determine the habitat availability and distribution of macroinvertebrates $[19,29]$. Deposition can evolve a stable floodplain as a habitat for invertebrates [32,33], but large resuspension/deposition could damage the macroinvertebrate community by physical, chemical, and indirect effects, such as abrasion, clogging, gradients of oxygen, and food availability [34,35]. Although a few studies involve the impacts of hyporheic flow patterns on the vertical distribution of certain species $[19,36]$, previous studies have not yet identified the potential changes in macroinvertebrate communities under hyporheic flow conditions $[10,11]$. Hence, it is necessary to investigate the magnitude and pattern (upwelling and downwelling) of hyporheic exchange, as they influence the dynamics of redox conditions and matter [37], and to characterize macroinvertebrate community structures using metrics such as abundance, composition, and diversity $[36,38]$. Additionally, water chemistry and sediment properties should be considered $[18,19,34,36,39,40]$.

In this study, the results from a field investigation carried out in the Weihe River and Beiluo River, which belong to the Weihe River Basin, are presented. The objectives of the present study are-(i) to explore the effects of hyporheic exchange pattern on the macroinvertebrate community in sediment, and (ii) to discuss the effects of hyporheic exchange magnitude on the macroinvertebrate community inside the sediment.

\section{Materials and Methods}

\subsection{Study Area}

The field study was conducted in the Weihe River basin, which covers an area of $134,766 \mathrm{~km}^{2}$ $\left(104^{\circ} 00^{\prime} \mathrm{E}-110^{\circ} 20^{\prime} \mathrm{E}, 33^{\circ} 50^{\prime} \mathrm{N}-37^{\circ} 18^{\prime} \mathrm{N}\right)$ in northwestern China, during May and June 2017 (Figure $\left.1 \mathrm{a}\right)$. The Weihe River, which is $818 \mathrm{~km}$ long and is the largest tributary of the Yellow River, originates in Gansu Province, and through the Guanzhong Plain of Shaanxi Province, discharges into the Yellow River. The Weihe River basin is a typical alluvial plain sandwiched between the Qinling Mountains in the south and the Loess Plateau in the north. Substrates in the Weihe River mainly consisted of clay, fine sand, and gravel. The Weihe River, fed by rainfall concentrated on July to October, has a mean annual runoff of $7.57 \times 10^{6} \mathrm{~m}^{3}$ and is also the main water supply in the Guanzhong region. The Beiluo River is the largest tributary of the Weihe River, with a total length of $680 \mathrm{~km}$. It originates in Shaanxi Province, and flows from northwest to southeast and discharges into the Weihe River with a mean annual runoff of $0.94 \times 10^{6} \mathrm{~m}^{3}$. On account of passing through the Loess region, Beiluo River is a sandy river with an annual sediment transport of 95.9 million tons. The Weihe River and Beiluo River are located in semiarid regions. Previous studies have shown that these two rivers are suitable for in situ 
testing on hyporheic exchange and have an abundant macroinvertebrate community [41,42]. In this investigation, 21 sampling sites in the alluvial plain were considered-12 sites (W1-W12) in the Weihe River and 9 sites (BL1-BL9) in the Beiluo River (Figure 1a). These rivers offer invertebrates the habitat which is mainly consisted of clay and fine sand.

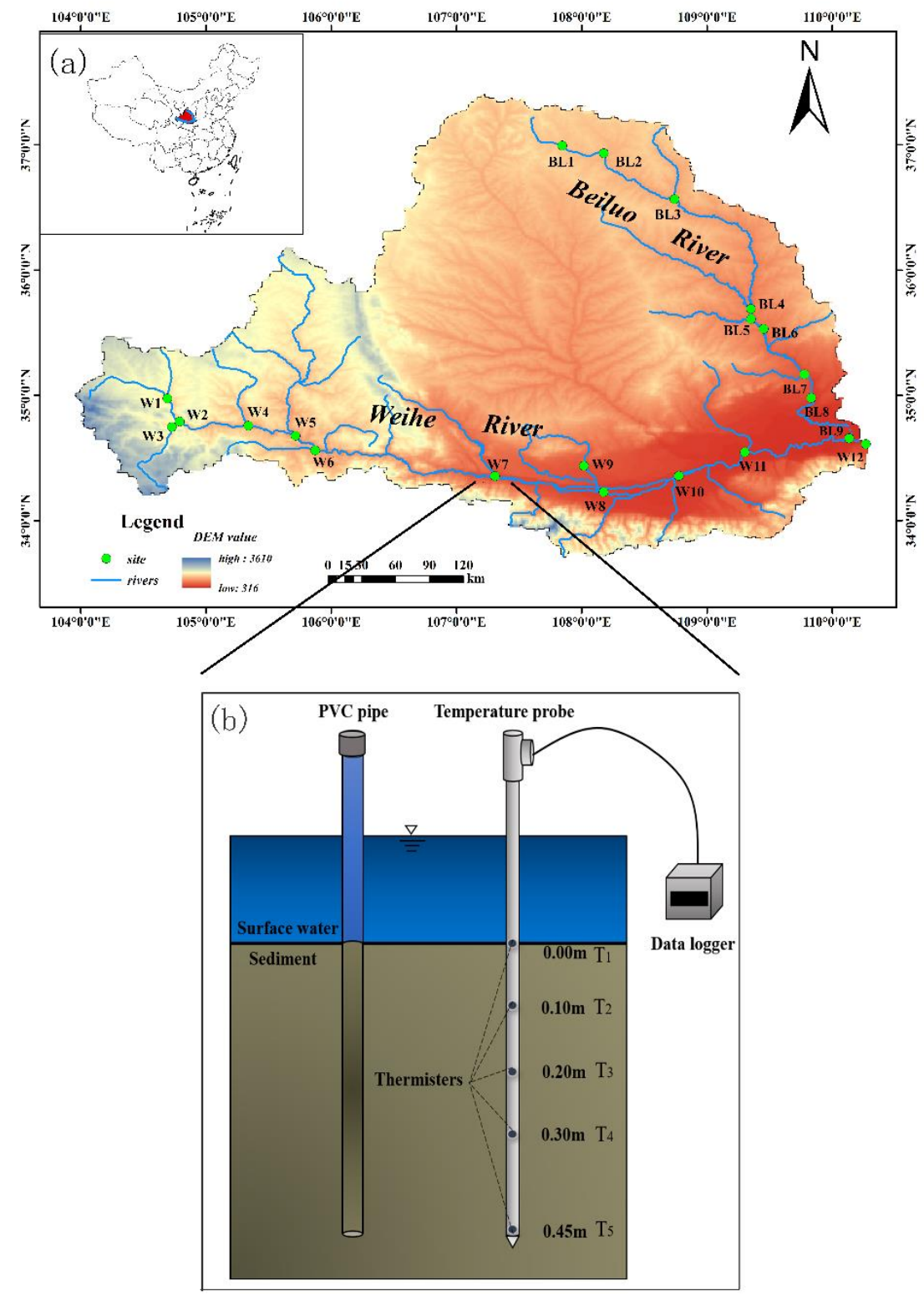

Figure 1. (a) Map with the location of field sampling sites in the Weihe River basin, and (b) Schematic diagram of the temperature probe and Polyvinyl Chloride (PVC) pipe.

\subsection{Hyporheic Exchange Determination}

A temperature probe (Figure 1b), which was equipped with thermistors on the metal tube, was inserted into the riffle downstream of the channel where no bridges or sharp bends were located, to measure the temperature of sediment at five different depths $(0.0,0.1,0.2,0.3$, and $0.45 \mathrm{~m})$ and hence, the temperature gradients were used to identify the patterns of hyporheic exchange [43]. Temperature measurements were recorded every 24 seconds by the data logger for approximately $30 \mathrm{~min}$ [44]. In 
steady-state conditions, the one-dimensional advection-conduction heat transport equation in the vertical direction for an incompressible fluid in a homogeneous porous medium was [45]:

$$
\frac{\partial^{2} T_{z}}{\partial z^{2}}-\frac{C_{f} \rho_{f} q}{k_{f s}}\left(\frac{\partial T_{z}}{\partial z}\right)=0
$$

where $z$ is the cartesian coordinate $\mathrm{z}(\mathrm{m}) ; \mathrm{Tz}$ represents the temperature at any depth $z\left({ }^{\circ} \mathrm{C}\right) ; q$ indicates the magnitude of hyporheic exchange flux $(\mathrm{m} / \mathrm{s}$, generally converted to $\mathrm{mm} / \mathrm{d})$. The remaining parameters are listed in Table 1. Assuming the following boundary conditions

$$
\begin{array}{ccc}
\mathrm{T}_{\mathrm{z}}=\mathrm{T}_{0} & \text { at } & \mathrm{z}=0 \\
\mathrm{~T}_{\mathrm{z}}=\mathrm{T}_{\mathrm{L}} & \text { at } & \mathrm{z}=\mathrm{L}
\end{array}
$$

The solution for Equation (1) is:

$$
\frac{\mathrm{T}_{\mathrm{z}}-\mathrm{T}_{0}}{\mathrm{~T}_{\mathrm{L}}-\mathrm{T}_{0}}=\mathrm{f}(\beta, \mathrm{z} / \mathrm{L})=\frac{\exp (\beta \mathrm{z} / \mathrm{L})-1}{\exp (\beta)-1}
$$

where $T_{0}$ and $T_{L}$ are the uppermost and lowermost temperature measurement, respectively $\left({ }^{\circ} \mathrm{C}\right) ; L$ is the vertical distance between the two boundaries $(\mathrm{m}) ; \beta$ is a dimensionless parameter, which could be positive or negative depending on whether $q$ is downward or upward (Equation (5)).

$$
\beta=\frac{C_{\mathrm{f}} \rho_{\mathrm{f}} \mathrm{qL}}{\mathrm{k}_{\mathrm{fs}}}
$$

Values of $\beta$ are obtained from a set of type-curves which are arithmetic plots of $f(\beta, z / L)$ against $z / L$ for different $\beta$ values. The specific value of $\beta$ is determined by a curve matching the measured data. Boyle and Saleem [46] used a computer procedure to calculate $\left(\left(T_{Z}-T_{0}\right)\right) /\left(\left(T_{L}-T_{0}\right)\right)$ as z changes from 0 to $L$, and computed the value of $\mathrm{F}(\beta)$ (Equation (6)). Arriaga and Leap [47] used Microsoft Excel

\begin{tabular}{|c|c|c|c|c|}
\hline \multirow{2}{*}{ Parameter } & \multirow{2}{*}{ Symbol } & \multicolumn{2}{|c|}{ Value } & \multirow{2}{*}{ Unit } \\
\hline & & Weihe River & Beiluo River & \\
\hline Thermal conductivity $[48,49]$ & $k_{f s}$ & 1.765 & 1.618 & $\mathrm{~J} \mathrm{~s}^{-1} \mathrm{~m}^{-1} \mathrm{~K}^{-1}$ \\
\hline Specific heat of fluid $[48,49]$ & $C_{f}$ & 4224 & 4224 & $\mathrm{~J} \mathrm{~kg}^{-1} \mathrm{~K}^{-1}$ \\
\hline Density of fluid & $\rho_{f}$ & 1000 & 1000 & $\mathrm{~kg} \mathrm{~m}^{-3}$ \\
\hline Vertical distance & $L$ & 0.45 & 0.45 & $\mathrm{~m}$ \\
\hline Turbulent Schmidt number $[28,50]$ & $S c_{T}$ & \multicolumn{2}{|c|}{1} & - \\
\hline Von Kármán constant [51] & $\kappa$ & \multicolumn{2}{|c|}{0.41} & - \\
\hline Fall (settling) velocity [52] & $w_{s}$ & \multicolumn{2}{|c|}{ related to particle size } & $\mathrm{m} \mathrm{s}^{-1}$ \\
\hline Roughness height [53] & $k_{s}$ & \multicolumn{2}{|c|}{0.003} & $\mathrm{~m}$ \\
\hline
\end{tabular}
Solver to obtain the optimum value of $\beta$ which yielded the minimum value of $F(\beta)$.

$$
F(\beta)=\sum_{z=0}^{z=L}\left[\frac{T_{z}-T_{0}}{T_{L}-T_{0}}-\frac{\exp (\beta z / L)-1}{\exp (\beta)-1}\right]^{2}
$$

Table 1. Parameters used for the calculation of hyporheic fluxes and Rouse number.

Finally, hyporheic exchange flux can be estimated as Equation (7).

$$
q=\frac{k_{f s} \beta}{C_{f} \rho_{f} L}
$$


Table 1 lists the value of the parameters in Equation (7). Negative and positive values of $q$ represent upwelling and downwelling, respectively.

\subsection{Water and Sediment Sampling}

Water samples were collected at a depth of $0.5 \mathrm{~m}$ below the river surface in the flow direction, using a polyethylene bottle of $1 \mathrm{~L}$ [54], and preserved using concentrated sulfuric acid for analysis by lowering the $\mathrm{pH}$ to $<2$. Water samples were stored in an icebox at $4{ }^{\circ} \mathrm{C}$ before laboratory analysis. The measured parameters and methods are listed in Table 2. Two measurements were taken for each sample, and the average value was calculated for further analysis. The chemical parameters of river water samples were subjected to the principal component analysis (PCA) in CANOCO 5 version (Software for Canonical Community Ordination) to determine the significant environmental variables due to hyporheic exchange. Redundancy analysis (RDA, SD $<3$ ) was performed to identify associations between the dominant family and major environmental variables [24].

Table 2. Determination of environmental conditions.

\begin{tabular}{|c|c|c|}
\hline Parameter & Method & Accuracy \\
\hline Total phosphorus (TP) & $\begin{array}{l}\text { The ammonium molybdate spectrophotometric } \\
\text { method (GB 11893-89, China) }\end{array}$ & $0.01 \mathrm{mg} \cdot \mathrm{L}^{-1}$ \\
\hline Total nitrogen $(\mathrm{TN})$ & $\begin{array}{l}\text { The alkaline potassium persulfate digestion-UV } \\
\text { spectrophotometric method (HJ 636-2012, China) } \mathrm{L}\end{array}$ & $0.01 \mathrm{mg} \cdot \mathrm{L}^{-1}$ \\
\hline $\mathrm{CO}_{3}^{2-}, \mathrm{HCO}_{3}^{-}$ & Titration by standard acid solution $(\mathrm{HCl}) \mathrm{L}$ & $0.01 \mathrm{mg} \cdot \mathrm{L}^{-1}$ \\
\hline $\mathrm{NH}_{4}^{+}, \mathrm{NO}_{3}^{-}, \mathrm{NO}_{2}^{-}, \mathrm{PO}_{3}{ }^{2-}$ & Ion chromatograph (Dionex-AQ, USA) ${ }^{\mathrm{L}}$ & $0.001 \mathrm{mg} \cdot \mathrm{L}^{-1}$ \\
\hline $\mathrm{pH}$ & & 0.01 \\
\hline Dissolved oxygen (DO) & Multiparameter water quality meter $(\mathrm{HACH}$ & $0.01 \mathrm{mg} \cdot \mathrm{L}^{-1}$ \\
\hline Oxidation-reduction potential (Eh) & HQ40d, USA) ${ }^{\mathrm{F}}$ & $0.1 \mathrm{mV}$ \\
\hline Water temperature $(\mathrm{T})$ & & $0.1^{\circ} \mathrm{C}$ \\
\hline Flow velocity & Velocimeter (MGG / KL-DCB) ${ }^{\mathrm{F}}$ & $0.001 \mathrm{~m} \cdot \mathrm{s}^{-1}$ \\
\hline
\end{tabular}

Note: F (measured in the field), L (measured in lab).

Sediment samples (three replicates within an area of $1 \mathrm{~m}^{2}$ ) were collected from 0 to $45 \mathrm{~cm}$ layers using a PVC pipe (lengths of $160 \mathrm{~cm}$ and an inner diameter of $5.4 \mathrm{~cm}$, Figure $1 \mathrm{~b}$ ) and every sample was placed in labelled bags to send to the laboratory [38]. All sediment samples were air-dried, screened for 20 minutes through different sieves for separation and each fraction was weighed by electronic-analytical balances (BT224S, $0.001 \mathrm{~g}$ ). Grain size data were used to derive the cumulative distribution functions (CDFs). $D_{50}$ was considered as a representative particle size parameter [52,55]. Thus, Rouse numbers were calculated to identify the predominant mode of sediment transport, i.e., bed load and suspended load. In this study, Rouse numbers were calculated using the fall velocity of $D_{50}$ particle size of the sediment [28]. The Rouse number is defined as:

$$
\mathrm{Z}_{\mathrm{R}}=\frac{\mathrm{Sc}_{\mathrm{T}} \mathrm{W}_{\mathrm{S}}}{\mathrm{Ku}^{*}}
$$

where ws is the fall (settling) velocity of the particle $\left(\mathrm{m} \mathrm{s}^{-1}\right) . S c_{T}$ is the turbulent Schmidt number [52]. $\kappa$ is von Kármán constant, and $\mathrm{u}^{*}$ is the shear velocity $\left(\mathrm{m} \mathrm{s}^{-1}\right)$, as in Equation (9). Shear velocity could be related to the average velocity as

$$
u^{*}=U \sqrt{\frac{f}{8}}
$$

where $U$ is the water average velocity $\left(\mathrm{m} \mathrm{s}^{-1}\right)$ and $f$ is the Darcy-Weisbach friction factor (dimensionless), which usually could be calculated through the Colebrook-White formula [53].

$$
\frac{1}{\sqrt{\mathrm{f}}}=-2 \log _{10}\left(\frac{\mathrm{k}_{\mathrm{s}}}{3.7 \mathrm{D}_{\mathrm{H}}}+\frac{2.51}{\mathrm{R}_{\mathrm{e}} \sqrt{\mathrm{f}}}\right)
$$


where $k_{s}$ is roughness height $(\mathrm{m}) . D_{H}$ is the hydraulic diameter $(\mathrm{m})$, and $R_{e}$ is the Reynolds number. Haaland [56] has proposed the following approximate solution of Equation (10).

$$
\frac{1}{\sqrt{\mathrm{f}}}=-1.81 \log _{10}\left[\frac{6.9}{\mathrm{R}_{\mathrm{e}}}+\left(\frac{\mathrm{k}_{\mathrm{s}}}{3.7 \mathrm{D}_{\mathrm{H}}}\right)^{1.11}\right]
$$

The values of the above parameters are listed in Table 1. The approach of Whipple [57] was applied to classify sediment transport as wash load $\left(Z_{R}<0.8\right)$, suspended load $\left(0.8<Z_{R}<2.5\right)$, and bed load $\left(Z_{R}>2.5\right)$.

\subsection{Macroinvertebrate Sampling}

Macroinvertebrates (three replicates) were sampled using a Surber sampler (area of bed covered $0.09 \mathrm{~m}^{2}, 0.3 \mathrm{~mm}$ mesh) within $5 \mathrm{~m}$ of the sediment sample. The quantitative sampling protocol followed Stark [58]. We rinsed the net thoroughly several times between replicates to concentrate and remove the macroinvertebrate from the net into a polyethylene bottle. We then preserved the sample by adding $75 \%$ ethanol. Macroinvertebrates were identified in the laboratory at the family level using a stereo dissecting microscope [59-61]. The characteristics of the macroinvertebrate community at each site were described using the following metrics-abundance $(N)$, dominance index $(Y, Y>0.02)$, diversity metrics: Pielou evenness index (J) [62], Shannon-Wiener diversity index (H) [63], and Margalef richness index (D) [64]. These metrics are largely applied in the literature [12,39]. These indicators derived the structural and composition metrics to present the macroinvertebrate community characteristics [39]. Independent-sample $t$-tests were performed on the hyporheic flux patterns and macroinvertebrate indices were calculated at each site to determine the effect of exchange patterns on the macroinvertebrate community. In this study, higher taxonomic levels of data classified by living habits (burrowers, swimmers, climbers, sprawlers, clingers, and divers) were used [65-67], because macroinvertebrates are sensitive to habitat changes $[68,69]$.

\section{Results}

\subsection{Hyporheic Exchange Fluxes and Macroinvertebrate Community}

All the sampling sites had a stable hydrological condition, without any abrupt environmental changes. The median values of hyporheic exchange were taken for further analysis and are shown in Table 3. The Kolmogorov-Smirnov test result of the flux fits a normal distribution at the site in both the Weihe River and Beiluo River $(p=0.106, p=0.112)$. Upwelling and downwelling with different magnitudes were observed during the study (Table 3 ).

A total of 3942 macroinvertebrates from 22 families were identified in the Weihe River and Beiluo River (Table 3). Burrowers, including Chironomidae (dominance index in the Weihe river $\left(\mathrm{Y}_{\mathrm{W}}\right)$ $=0.21$, dominance index in the Beiluo river $\left.\left(\mathrm{Y}_{\mathrm{B}}\right)=0.64\right)$, Tubificidae $\left(\mathrm{Y}_{\mathrm{w}}=0.35, \mathrm{Y}_{\mathrm{B}}=0.18\right)$, and swimmers, such as Baetidae $\left(\mathrm{Y}_{\mathrm{w}}=0.07\right)$, which are the most dominant families, were largely observed in sampling sites. In addition, a quantity of clingers (e.g., Hydropsychidae), climbers, sprawlers, and divers was also observed (Figure 2 and Table 3). The average values of abundance and diversity index of macroinvertebrates in downwelling (232 individuals, $H=1.56, J=0.72, D=2.20$ ) were greater than those for upwelling (138 individuals, $H=1.17, J=0.56, D=1.53$ ) (Figure 2c). Compositions of communities were different between the upwelling and downwelling. Ten families (approximately $46 \%$ of the total number of families) were found in both upwelling and downwelling sites, such as Chironomidae and Tubificidae. Eight families (approximately $36 \%$ of the total number of families) were found only in downwelling sites, such as Dryopidae and Planorbidae. Four families (approximately $18 \%$ of the total number of families) were found only in the upwelling sites, such as Aeschnidae and Gammaridae (Table 3). 
Table 3. Hyporheic exchange flux, families of communities, and Rouse number.

\begin{tabular}{|c|c|c|c|c|}
\hline & Site & $\begin{array}{l}\text { Magnitude of Flux } \\
(\mathrm{mm} / \mathrm{d})\end{array}$ & $\begin{array}{l}\text { Rouse Number } \\
\left(Z_{R}, \text { Mode }\right)\end{array}$ & Families of Communities \\
\hline \multirow{10}{*}{ Upwelling } & W1 & -179.48 & $0.47(\mathrm{w})$ & Chironomidae (U, D) \\
\hline & W2 & -108.15 & $0.93(\mathrm{~s})$ & Tubificidae (U, D) \\
\hline & W3 & -93.12 & $0.26(w)$ & Dryopidae (D) \\
\hline & W4 & -143.42 & $1.15(\mathrm{~s})$ & Hydropsychidae (U, D) \\
\hline & W6 & -114.48 & - & Perlidae (U, D) \\
\hline & W8 & -298.10 & $2.07(\mathrm{~s})$ & Staphylinidae (D) \\
\hline & W9 & -247.66 & - & Tipulidae (U, D) \\
\hline & BL6 & -55.39 & - & Aeschnidae (U) \\
\hline & BL7 & -88.74 & - & Lymnaeidae (U, D) \\
\hline & BL8 & -226.30 & $0.06(w)$ & Macromiidae (D) \\
\hline \multirow{11}{*}{ Downwelling } & W5 & 147.75 & - & $\begin{array}{l}\text { Physidae (U, D) } \\
\text { Planorbidae (D) }\end{array}$ \\
\hline & W7 & 98.68 & $0.20(w)$ & Saldidae (U) \\
\hline & W10 & 125.41 & $3.70(\mathrm{~b})$ & Viviparidae (D) \\
\hline & W11 & 224.76 & - & Ephydridae (D) \\
\hline & W12 & 103.32 & - & Herpodellidae (U, D) \\
\hline & BL1 & 233.59 & - & Gammaridae (U) \\
\hline & BL2 & 131.92 & $3.70(b)$ & Glossiphonidae (U) \\
\hline & BL3 & 177.01 & - & Psychodidae (D) \\
\hline & BL4 & 88.10 & - & Baetidae (U, D) \\
\hline & BL5 & 49.68 & - & Corixidae (D) \\
\hline & BL9 & 91.42 & - & Dytiscidae (U, D) \\
\hline
\end{tabular}

Note-wash load (w), suspended load (s), bed load (b), found at upwelling site (U), found at downwelling site (D). Rouse numbers for W5-W6, W9, W11-BL1, BL3-BL7, and BL9 were smaller than 0.8 and they are not listed.
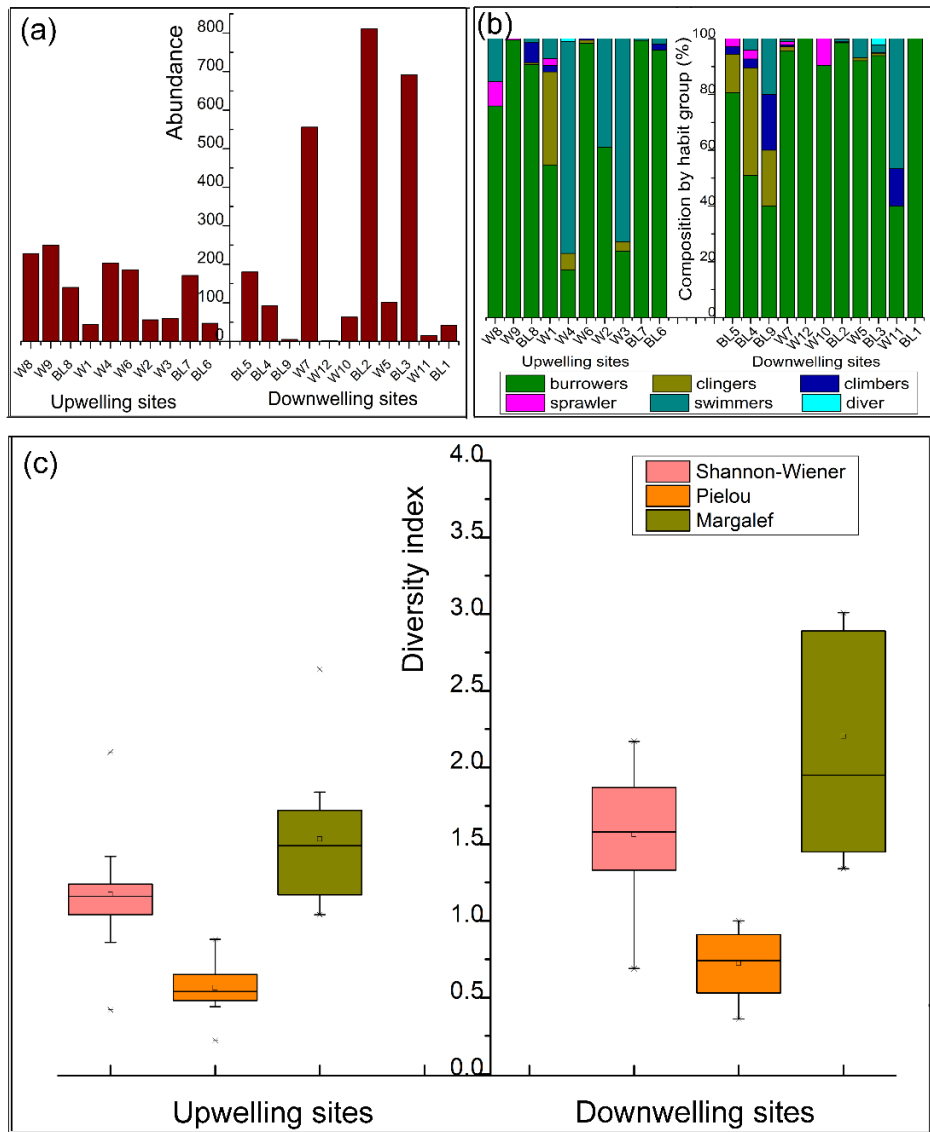

Figure 2. Macroinvertebrate community structure (a) total abundance, (b) the composition by habit group, and (c) the diversity indices. Sites were ordered from the most negative flux to the most positive flux. 


\subsection{Sediment Transport and Water Quality}

The Rouse number for uniform clay sites was smaller than 0.8 and it is not listed. The sediment transport mode was significant different between all sampling sites (average $=2.09$, variance $=2.09$ ) (Table 3). Compared to the downwelling (average $=2.53, \mathrm{SD}=2.20$ ), upwelling flow tended to produce notable resuspension (average $=0.82, \mathrm{SD}=0.73$ ), such as $\mathrm{W} 2, \mathrm{~W} 4$, and $\mathrm{W} 8$.

Principal component analysis (PCA) for the chemical characteristics of river water samples was performed. Figure 3 a shows the environmental variance of the Weihe River and the first two PCs can identify $72.2 \%$ of the information in the raw data. Figure $3 b$ represents the Beiluo River and the first two PCs have the cumulative interpretation of a variance of $85 \%$. There were some parameters correlated with the two PCs (correlation coefficient with horizontal or vertical axis greater than 0.5), such as $\mathrm{CO}_{3}{ }^{2-}, \mathrm{HCO}_{3}{ }^{-}, \mathrm{NO}_{2}-\mathrm{N}, \mathrm{NO}_{3}-\mathrm{N}, \mathrm{NH}_{4}-\mathrm{N}$ T-N, TP, DO, and $\mathrm{T}$ (temperature). The results of an independent-sample $t$-test performed on the hyporheic flux patterns and concentration of chemical indictors demonstrated that $\mathrm{NH}_{4}-\mathrm{N}(p=0.027)$ and $\mathrm{HCO}_{3}{ }^{-}(p=0.049)$ were significantly influenced by the hyporheic exchange patterns. Several upwelling sites (yellow circle) were positively correlated to $\mathrm{NH}_{4}{ }^{+}, \mathrm{NO}_{3}{ }^{-}$, and $\mathrm{TN}$ concentrations (Figure 3a), speculating upwelling sites were trending to be positively correlated to $\mathrm{NH}_{4}{ }^{+}, \mathrm{NO}_{3}{ }^{-}$, and $\mathrm{TN}$ concentrations (Figure 3a). Several downwelling sites (blue circle) were highly correlated to the $\mathrm{HCO}_{3}{ }^{-}$concentrations (Figure 3b), indicating downwelling sites were correlated to $\mathrm{HCO}_{3}{ }^{-} / \mathrm{CO}_{3}{ }^{2-}$ concentrations (Figure 3a). However, temperature $(p=0.246)$ was not significantly affected by hyporheic patterns. Both upwelling and downwelling sites appearing in green circles were close to the temperature arrow (Figure 3a), indicating two patterns of hyporheic exchange were all strongly correlated to the water temperature. Therefore, curves of the magnitude with temperature, downwelling with Rouse number, $\mathrm{DO}, \mathrm{HCO}_{3}{ }^{-}, \mathrm{CO}_{3}{ }^{2-}$, and upwelling with nutrient $\left(\mathrm{NO}_{3}-\mathrm{N}, \mathrm{NO}_{2}-\mathrm{N}, \mathrm{NH}_{4}-\mathrm{N}\right)$ were fitted (Figure 4). Water temperature of downwelling was greater than that of the upwelling (Figure $4 \mathrm{~b}$ ). Dissolved oxygen increases with the magnitude, which was greater than $150 \mathrm{~mm} / \mathrm{d}$ (Figure 4c). The $\mathrm{HCO}_{3}{ }^{-}$and $\mathrm{CO}_{3}{ }^{2-}$ increased as the magnitude increased and reached a maximum at a hyporheic flux of 150-200mm/d. It was lower than the level of flux (250-300 mm/d) reaching the maximum nutrient concentrations (Figure $4 \mathrm{~d}, \mathrm{e}$ ).

\subsection{Influence of the Pattern of Hyporheic Exchange on Macroinvertebrates}

The abundance of macroinvertebrate communities at upwelling/downwelling sampling sites showed variability (Figure 2a). Although the difference in macroinvertebrate abundance at the upwelling sites was relatively small $(\mathrm{SD}=76.32$, abundance $=138)$, the downwelling process was more prone to high abundance $(S D=287.22$, abundance $=232)$ (Figure 2a). Additionally, the swimmer group had an average community composition of $20.59 \%, 43.41 \%$, and $0.50 \%$ in the wash load, suspension load, and bed load, respectively. Obviously, it increased under resuspension (Table 3, Figure 2b). The abundance of macroinvertebrates under high suspended load and bed load was significantly larger than that for high wash load $(\mathrm{RSD}=67.3 \%$ and $66.2 \%)$. The results of independent-sample $t$-tests demonstrated that the Shannon-Wiener index $(p=0.047)$ and Margalef index $(p=0.017)$ were significantly influenced by the hyporheic exchange patterns. Additionally, the average values of the Shannon-Wiener indices $(H=1.56)$ and Margalef indices $(\mathrm{D}=2.20)$ in downwelling sites was significantly greater than in upwelling sites $(\mathrm{H}=1.17, \mathrm{D}=1.53)$. Thus, macroinvertebrates in upwelling sites was found to have lower diversity and richness than in downwelling sites (Figure 2c). 

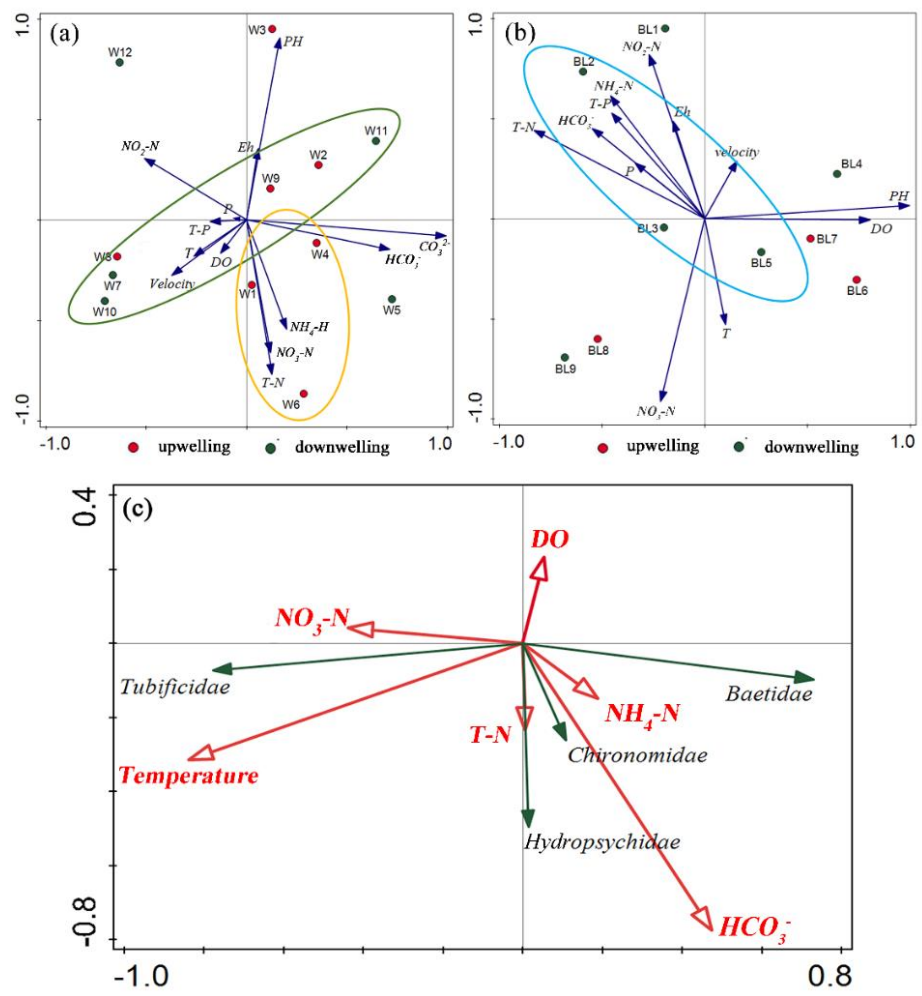

Figure 3. Principle component analysis (PCA) of (a) the Weihe River and (b) Beiluo River (c) redundancy anaylsis (RDA) of principal macroinvertebrate family and environmental variation. The green circle and yellow circle are the distribution area of Weihe river sites that are close to the temperature and nutrient $\left(\mathrm{NO}_{3}-\mathrm{N}, \mathrm{T}-\mathrm{N}, \mathrm{NH}_{4}-\mathrm{N}\right)$ arrows, respectively. The blue circle is the distribution area of Beiluo river sites that are close to the $\mathrm{HCO}_{3}{ }^{-}$arrow.
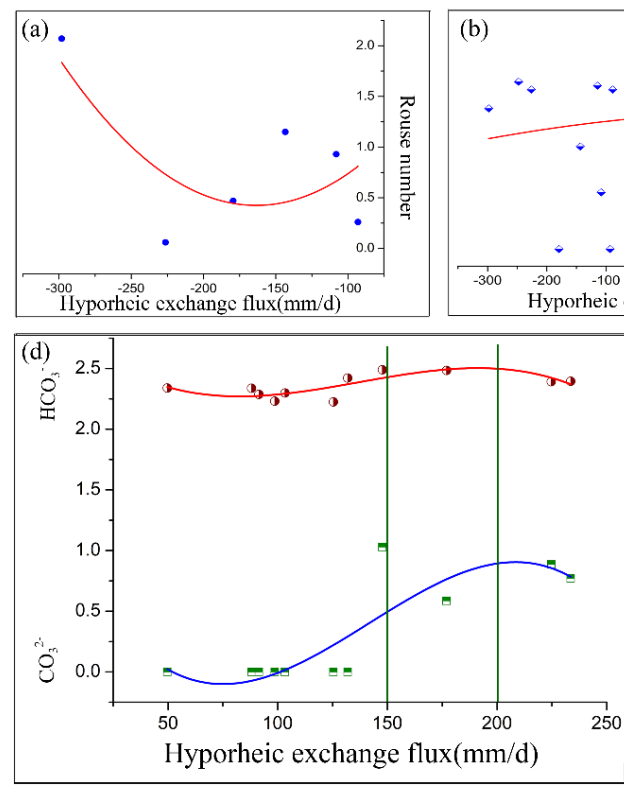
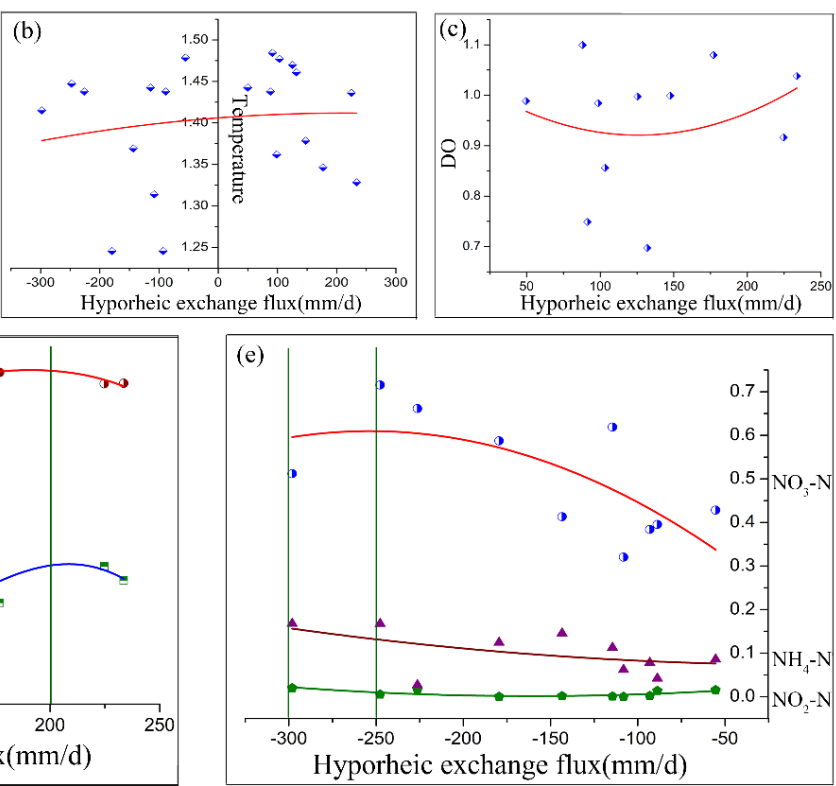

Figure 4. Trend of hyporheic exchange magnitude on water quality indicators (a) Rouse number (b) temperature (c) $\mathrm{DO}(\mathbf{d}) \mathrm{HCO}_{3}{ }^{-}$(red line) and $\mathrm{CO}_{3}{ }^{2-}$ (blue line) (e) $\mathrm{NO}_{3}-\mathrm{N}$ (red line), $\mathrm{NO}_{2}-\mathrm{N}$ (green line) and $\mathrm{NH}_{4}-\mathrm{H}$ (purple line). The maximum value can be found in the magnitude between the green auxiliary lines. 
Redundancy analysis (RDA) was used to explain the relationship between the principal family and the major environmental variation (i.e., $\mathrm{HCO}_{3}{ }^{-}, \mathrm{NO}_{3}-\mathrm{N}, \mathrm{NH}_{4}-\mathrm{N}, \mathrm{T}-\mathrm{N}, \mathrm{DO}$, temperature) (Figure 3c). The data from the Weihe River and Beiluo River were combined to increase the reliability of RDA analysis results (W11, W12, and BL9 sites with a few individuals not included). The first two axes explained $93.64 \%$ of the variations $(p=0.048<0.05)$. RDA analysis indicated that Hydropsychidae had a strong dependence on TN. Chironomidae was positively correlated to $\mathrm{HCO}_{3}{ }^{-}, \mathrm{NH}_{4}-\mathrm{N}$, and T-N. Tubificidae was positively correlated to the temperature. Baetidae was strongly influenced by $\mathrm{NH}_{4}-\mathrm{N}$ and negatively correlated to temperature.

\subsection{Influence of the Magnitude of Hyporheic Exchange on Macroinvertebrates}

The magnitude of hyporheic fluxes was divided into four classes, corresponding to 50-100, 100-150, 150-200, and 200-250 mm/d (points in other ranges were too few to be considered, Figure 5). All mean index values of abundance and diversity indices $(\mathrm{N}=368 ; \mathrm{H}=2.14 ; \mathrm{J}=0.81 ; \mathrm{D}=2.70)$ of 150-200 mm/d (represented by the color different from the other three classes) were greater than other classes, indicating the richest or most diverse macroinvertebrate community was found at this level (Figure 5). Below the magnitude, such as for 50-100 mm/d and 100-150 mm/d, increasing flux was associated with a greater abundance and diversity of macroinvertebrates. Beyond the magnitude, i.e., above $200-300 \mathrm{~mm} / \mathrm{d}$, the macroinvertebrates were less and diversity of community was declined.
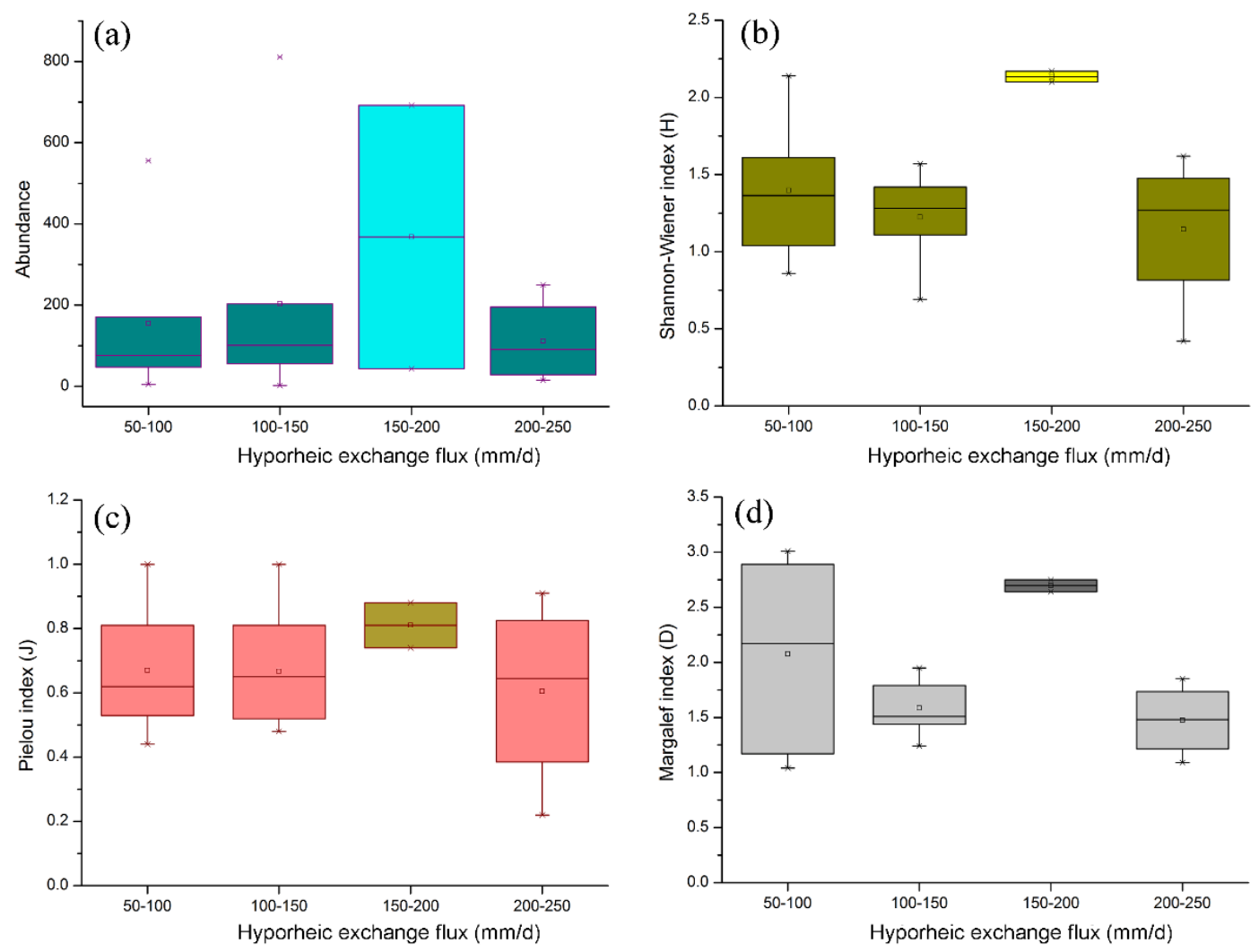

Figure 5. Box plots of hyporheic exchange flux magnitude and macroinvertebrate community. (a) Abundance (b) Shannon-Wiener index (c) Pielou index and (d) Margalef index. The class with the greatest mean value of the index was represented by a color different from the other three classes. 


\section{Discussion}

\subsection{Effect of Upwelling Dynamics on Macroinvertebrate Communities}

Upwellings did not produce as rich invertebrate communities as downwelling. This is consistent with the conclusions of the studies in Speed River in southern Ontario, Canada, and in southern Hawke's Bay, New Zealand [36,37]. Strong upwelling could directly carry the tiny organisms away from the sediment. More importantly, it simultaneously returns sediment to the surface layer, especially fine particles, enhancing resuspension [25,70]. It is difficult for the organisms to survive in the sediment with too many fine particles, as they create a physical barrier by clogging, with burial effects on the macroinvertebrate community $[35,71]$. However, the macroinvertebrate abundance under resuspension in this study was not significantly reduced in comparison with the bed load. This finding is likely attributable to the different adaptive performances of macroinvertebrates in the suspension. Total suspended solid (TSS) increases drive the movement of organisms and spread of the macroinvertebrates from the cluster by physical effects [35,72], affecting the community structure. Burrowers can inhabit the deeper sediment because of their ability of building channels [73]. However, the large resuspension allowed the swimmer group, especially Baetidae, to gather on the surface and to drift away from the riverbed. In this study it was clear that TSS increased the swimmer proportion in the community due to its aggregation. Therefore, the effect of sediment resuspension on burrowers (the most dominant habit group in the community) was weak, yet the effect on swimmers is greater. This is in agreement with the study of the effects of resuspension on macroinvertebrates in the Cinca River [40]. A low rate of resuspension, compared to the large rates, caused few macroinvertebrates to drift away from the riverbed, resulting in an abundant community in the Weihe River. Similarly, the abundance of macroinvertebrates decreases in drift related to sediment load, which has been reported for the Pyrenean river [40]. Therefore, a low suspended load is beneficial to the community to maintain its abundance.

On the other hand, groundwater acts as the principal source of nitrogen and phosphorus on account of the agricultural soil leaching and filtration, as well as underground low oxygen environments [22,74]. Therefore, upwelling sites were positively correlated to $\mathrm{NH}_{4}{ }^{+}, \mathrm{NO}_{3}{ }^{-}$, and $\mathrm{TN}$ concentrations (Figure 3a). This indicated that groundwater upwelling could transport nutrients from the aquifer to the stream [48]. However, different nitrogen nutrients had different effects on the diverse family, and may even have negative effects (Figure 3c). Thus, nutrient concentrations may also degrade the structure and function of the macroinvertebrate community and reduce biological diversity $[59,75]$.

\subsection{Effect of Downwelling Dynamics on Macroinvertebrate Communities}

In this study, it was difficult to observe the significant effect of downwelling on sediments because of the limited data. However, downwelling may cause relatively coarse particles in bed sediment [25], which, in turn, may prevent the damage of macroinvertebrates from fine sediment. Severe deposition caused by an accumulation of particle sediments through downwelling could prevent macroinvertebrates from being buried in deeper sediments [19,25]. Therefore, it is worthwhile to study the effect on the macroinvertebrates of the downwelling on the sediment. Actually, experiments in streams using trays filled with substrata should be conducted in future research to investigate the response of macroinvertebrates to sediment deposition [76].

The hyporheic zone receives oxygen from the surface water only [9]. Downwelling dictates oxygen concentration in the HZ [77]. No single family showed a response to DO that was markedly stronger than another family (Figure 3c). This indicates that all these major families had a universal dependence on DO, which it is associated with the widespread aerobic respiration in macroinvertebrates [78,79]. Therefore, DO carried by the downwelling provides the necessary conditions for a rich community to some extent. Macroinvertebrate metabolism consumes organic matter and produces dissolved inorganic carbon (DIC, mainly the greenhouse gas $\mathrm{CO}_{2}$ ), affecting surface water quality [80,81]. Downwelling was more correlated with $\mathrm{HCO}_{3}{ }^{-}$and $\mathrm{CO}_{3}{ }^{2-}$ than upwelling (Figure 3a,b). Moreover, 
groundwater had a low organic matter content, and it was not considered as a major source of organic matter supporting hyporheic organisms [82]. This indicated that downwelling can affect the growth of invertebrate communities by removing organic matter from the river, which controls their metabolism. This finding is supported by the literature on carbon cycling $[77,83]$. Chironomidae were dependent on $\mathrm{HCO}_{3}{ }^{-}$(Figure $3 \mathrm{c}$ ), hence, their demand for organic matter was more pronounced. This is consistent with Lee [84], who found that decomposition of leaf litter increased dissolved $\mathrm{CO}_{2}$, and subsequently promoted the growth of the Chironomidae community. Thus, downwelling may allow Chironomidae to become the dominant family.

Both patterns of hyporheic exchange participate in the regulation of temperature [21], and maintain a suitable thermal niche (temperature range) for macroinvertebrate survival [85]. Actually, whichever environment and pattern of hyporheic flux provide temperatures closer to the macroinvertebrate requirements would likely be preferred. Consequently, preference of different families for upwelling or downwelling could depend on different environments, such as regions and seasons. It was found that temperature was correlated with Tubificidae and Baetidae in the Weihe River basin during the test period (Figure 3c). Water temperature in the Weihe River basin adjusted by upwelling or downwelling to be maintained at $16-27^{\circ} \mathrm{C}$, which is close to the temperature $\left(15-25^{\circ} \mathrm{C}\right)$ found by Lou [72], increases the growth rate of Tubificida. Additionally, Tubificidae is a pollution-tolerant oligochaete that can tolerate the adverse effects of temperature fluctuations and pollutants caused by different exchanges [81]. Therefore, Tubificidae can persist in both upwelling and downwelling sites, promoting the dominance of the burrower in the community (Figure 3a). Water temperature of downwelling was greater than that of the upwelling (Figure 4b). However, larval of Baetidae growth was exponential in low temperatures $\left(11^{\circ} \mathrm{C}\right)[86]$, which is another reason for the Baetidae increase in upwelling.

Collectively, upwelling is controlling the transport of nutrients from groundwater to the river and it easily produces suspended particles in the river. By contrast, downwelling is controlling the transport of DOC and DO from the river to the groundwater. Deposition caused by particle accumulation through downwelling needs to be further studied. Temperature regulation is the common mechanism in both upwelling and downwelling (Figure 6) [36,87].

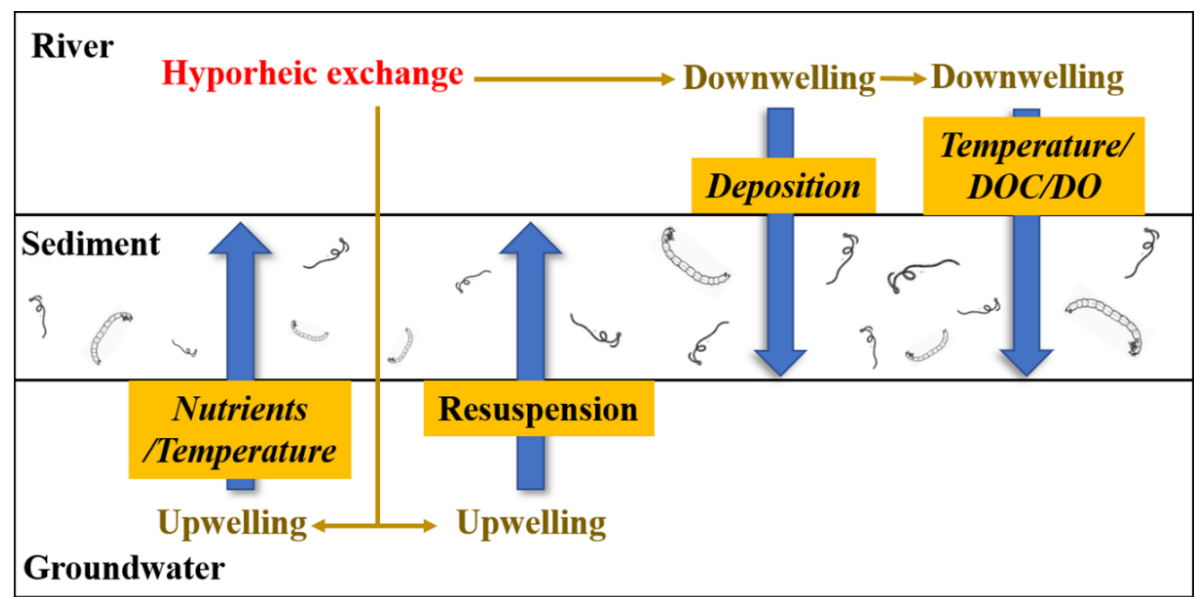

Figure 6. Diagram of the influence mechanism of hyporheic exchange patterns on the macroinvertebrate community.

\subsection{Effect of Hyporheic Exchange Magnitude on Macroinvertebrate Community}

Fine sediment undergoes a process of resuspension/deposition changes as the hyporheic exchange increases (Figure 4a). This is related to the flocculation caused by the collision of resuspended particles that accelerates the deposition rate of fine particles and forms mud $[70,88]$. However, it is hard to say that the variation of sediment resuspension is only due to the fluctuations of the hyporheic flux magnitude, because discharge, as the main driver of morphology, could generate bed mobility, resulting 
in morphological changes $[89,90]$. Therefore, it is still difficult to quantify the relationship between the resuspension and the variation of hyporheic exchange magnitude. Furthermore, there are physical actions between hyporheic exchange and river bedforms and subsurface geophysical features $[7,91]$. The question of whether hyporheic flow induces the bedform dynamics to affect the macroinvertebrate community is important and should be addressed in future research.

A total of $150-200 \mathrm{~mm} / \mathrm{d}$ was the optimal magnitude to promote the survival of the community in this study (Figure 5). It is also the critical point. Macroinvertebrate communities are less sensitive to thermal control [92], of which changing was very slow $(|a|<$ E-6, Figure $4 b)$. Concentration of DO, which decreased in the optimal magnitude of macroinvertebrates, has no relationship with the vertical hydraulic gradient produced by the hyporheic exchange [93]. Therefore, variational temperature and DO concentrations caused by different magnitudes of hyporheic flux would not affect the abundance and diversity of macroinvertebrate communities. Additionally, organic carbon assimilated by macroinvertebrates is increasing as the magnitude increases (Figure 4d) [94]. The magnitude $(250-300 \mathrm{~mm} / \mathrm{d})$ that had the maximum concentrations of nutrients was higher than the magnitude (150-200 mm/d) that had the highest abundance, biodiversity, $\mathrm{HCO}_{3}{ }^{-}$, and $\mathrm{CO}_{3}{ }^{2-}$ concentrations (Figure 5), indicating that the decrease of abundance and diversity could be related to the excessive nutrients [22]. Thus, during the investigation of the Weihe River basin, hyporheic exchange with a rate of $150-200 \mathrm{~mm} / \mathrm{d}$ provided sufficient organic carbon, stable temperature, and DO, as well as appropriate nutrients for the macroinvertebrates, ensuring an abundant and rich community. Below $150-200 \mathrm{~mm} / \mathrm{d}$, organic carbon supply to the invertebrate community could be insufficient. Above 150-200 mm/d, a large quantity of nutrients could limit their development. Future research can explore the classification criteria of the classes and conduct experiments at more sites to improve the accuracy of the results. Anyway, more research on the investigation of the optimal magnitude of the macroinvertebrates is welcome.

\section{Conclusions}

In this study, the effect of the pattern and magnitude of hyporheic exchange on the macroinvertebrate community of the Weihe River basin was presented and discussed. The data were collected during a field test conducted in these rivers in May and June of 2017.

Downwelling controlled the transport processes of dissolved oxygen (DO) and dissolved organic carbon (DOC), which are commonly required for macroinvertebrates. It produced abundant and rich macroinvertebrate communities and was beneficial to Chironomidae to become the dominant family. In contrast, upwelling improved the proportion of swimmers (e.g., Baetidae) in the macroinvertebrate community by sediment resuspension, yet resulted in a reduced abundance within the overall macroinvertebrate community. Moreover, upwelling was responsible for transporting nutrients. However, different responses (promoted or restricted) of each family to diverse nitrogen nutrients results in the nutrients delivered by the upwelling meant they were not necessarily beneficial to all individuals and families in the community. Both upwelling and downwelling regulate the water temperature and could provide a suitable thermal niche that promotes the growth of Tubificidae. A rate for the hyporheic flux of 150-200 $\mathrm{mm} / \mathrm{d}$ was optimal for the macroinvertebrate community in the Weihe River basin. However, below this rate, any increase of rate could boost the organic carbon to promote their abundance and diversity. Exceeding this range may provide high concentrations of nutrients to the community which limits their development.

This study supports any activities to preserve the ecological functions and health of the rivers dominated by fine-particle sediment (sand and clay). However, the effects of hyporheic fluxes across bedforms on macroinvertebrate communities could be investigated in future studies. In addition to invertebrates, other large organisms and their behaviors, such as salmonid spawning, are also affected by hydrological processes, gravel quality [95], and temperature [96]. To better identify the effect of downwelling and upwelling on organisms, the larger scale biotic responses (such as fish) should be also assessed. 
Author Contributions: Q.L. carried out experiments and wrote the original draft preparation. J.S. contributed in conceiving, designing, and supervising the research. C.G. revised the manuscript. D.C., P.S., X.W., J.F., and J.P. assisted with performing the experiments. All authors have read and agreed to the published version of the manuscript.

Funding: This study was supported by the National Natural Science Foundation of China (Grant Nos. 51679200 and 51379175), Science and Technology Project of Shaanxi Provincial Water Resources Department (Grant No. 2018slkj-12), and the Hundred Talents Project of the Chinese Academy of Sciences (Grant No. A315021406).

Acknowledgments: We are grateful to members for the experiment assistance. In particular, we are grateful to the editor and anonymous reviewers for providing numerous comments and suggestions, which helped improve the manuscript.

Conflicts of Interest: The authors declare no conflict of interest.

\section{References}

1. Stanford, J.A.; Ward, J.V. The hyporheic habitat of river ecosystems. Nature 1988, 335, 64. [CrossRef]

2. Datry, T.; Larned, S.T. River flow controls ecological processes and invertebrate assemblages in subsurface flowpaths of an ephemeral river reach. Can. J. Fish. Aquat. Sci. 2008, 65, 1532-1544. [CrossRef]

3. Meyer, C.K.; Peterson, S.D.; Whiles, M.R. Quantitative assessment of yield, precision, and cost-effectiveness of three wetland invertebrate sampling techniques. Wetlands 2011, 31, 101-112. [CrossRef]

4. Abowei, J.F.N. Salinity, dissolved oxygen, $\mathrm{pH}$ and surface water temperature conditions in Nkoro River, Niger Delta, Nigeria. Adv. J. Food Sci. Technol. 2010, 2, 36-40.

5. Findlay, S. Importance of surface-subsurface exchange in stream ecosystems: The hyporheic zone. Limnol. Oceanogr. 1995, 40, 159-164. [CrossRef]

6. Jin, G.; Jiang, Q.; Tang, H.; Li, L.; Barry, D.A. Density effects on nanoparticle transport in the hyporheic zone. Adv. Water Resour. 2018, 121, 406-418. [CrossRef]

7. Gualtieri, C. Bedforms-induced hyporheic exchange: Impact of the porous medium permeability. In Bold Visions for Environmental Modelling, Proceedings of the iEMSs Seventh Biennial Meeting: International Congress on Environmental Modelling and Software, San Diego, CA, USA, 15-19 June 2014; Ames, D.P., Quinn, N.W.T., Rizzoli, A.E., Eds.; pp. 2084-2091. ISBN 978-88-9035-744-2.

8. Grant, S.B.; Gomez-Velez, J.D.; Ghisalberti, M. Modeling the Effects of Turbulence on Hyporheic Exchange and Local-to-Global Nutrient Processing in Streams. Water Resour. Res. 2018, 54, 5883-5889. [CrossRef]

9. Tonina, D.; Buffington, J.M. Hyporheic exchange in mountain rivers I: Mechanics and environmental effects. Geogr. Compass 2009, 3, 1063-1086. [CrossRef]

10. Rawi, C.S.M.; Al-Shami, S.A.; Madrus, M.R.; Ahmad, A.H. Biological and ecological diversity of aquatic macroinvertebrates in response to hydrological and physicochemical parameters in tropical forest streams of Gunung Tebu, Malaysia: Implications for ecohydrological assessment. Ecohydrology 2014, 7, 496-507. [CrossRef]

11. Peralta-Maraver, I.; Reiss, J.; Robertson, A.L. Interplay of hydrology, community ecology and pollutant attenuation in the hyporheic zone. Sci. Total Environ. 2018, 610, 267-275. [CrossRef]

12. Stubbington, R.; Wood, P.J.; Reid, I.; Gunn, J. Benthic and hyporheic invertebrate community responses to seasonal flow recession in a groundwater-dominated stream. Ecohydrology 2011, 4, 500-511. [CrossRef]

13. Harvey, J.; Gooseff, M. River corridor science: Hydrologic exchange and ecological consequences from bedforms to basins. Water Resour. Res. 2015, 51, 6893-6922. [CrossRef]

14. Cai, Y.; Yue, W.; Xu, L.; Yang, Z.; Rong, Q. Sustainable urban water resources management considering life-cycle environmental impacts of water utilization under uncertainty. Resour. Conserv. Recycl. 2016, 108, 21-40. [CrossRef]

15. Wang, G.; Liu, S.; Liu, T.; Fu, Z.; Yu, J.; Xue, B. Modelling above-ground biomass based on vegetation indexes: A modified approach for biomass estimation in semi-arid grasslands. Int. J. Remote Sens. 2019, 40, 3835-3854. [CrossRef]

16. Todeschini, S.; Papiri, S.; Sconfietti, R. Impact assessment of urban wet-weather sewer discharges on the Vernavola river (Northern Italy). Civ. Eng. Environ. Syst. 2011, 28, 209-229. [CrossRef]

17. Cai, Y.; Rong, Q.; Yang, Z.; Yue, W.; Tan, Q. An export coefficient based inexact fuzzy bi-level multi-objective programming model for the management of agricultural nonpoint source pollution under uncertainty. $J$. Hydrol. 2018, 557, 713-725. [CrossRef] 
18. Stegen, J.C.; Johnson, T.; Fredrickson, J.K.; Wilkins, M.J.; Konopka, A.E.; Nelson, W.C.; Arntzen, E.V.; Chrisler, W.B.; Chu, R.K.; Fansler, S.J.; et al. Influences of organic carbon speciation on hyporheic corridor biogeochemistry and microbial ecology. Nat. Commun. 2018, 9, 1-11. [CrossRef]

19. Mathers, K.L.; Millett, J.; Robertson, A.L.; Stubbington, R.; Wood, P.J. Faunal response to benthic and hyporheic sedimentation varies with direction of vertical hydrological exchange. Freshw. Biol. 2014, 59, 2278-2289. [CrossRef]

20. Marzadri, A.; Tonina, D.; Bellin, A. Quantifying the importance of daily stream water temperature fluctuations on the hyporheic thermal regime: Implication for dissolved oxygen dynamics. J. Hydrol. 2013, 507, 241-248. [CrossRef]

21. Briggs, M.A.; Buckley, S.F.; Bagtzoglou, A.C.; Werkema, D.D.; Lane, J.W., Jr. Actively heated high-resolution fiber-optic-distributed temperature sensing to quantify streambed flow dynamics in zones of strong groundwater upwelling. Water Resour. Res. 2016, 52, 5179-5194. [CrossRef]

22. Xia, X.; Zhang, S.; Li, S.; Zhang, L.; Wang, G.; Zhang, L.; Wang, J.; Li, Z. The cycle of nitrogen in river systems: Sources, transformation, and flux. Environ. Sci. Proc. Imp. 2018, 20, 863-891. [CrossRef] [PubMed]

23. Woodward, G.; Gessner, M.O.; Giller, P.S.; Gulis, V.; Hladyz, S.; Lecerf, A.; Malmqvist, B.; McKie, B.G.; Tiegs, S.D.; Cariss, H.; et al. Continental-scale effects of nutrient pollution on stream ecosystem functioning. Science 2012, 336, 1438-1440. [CrossRef] [PubMed]

24. Von Fumetti, S.; Bieri-Wigger, F.; Nagel, P. Temperature variability and its influence on macroinvertebrate assemblages of alpine springs. Ecohydrology 2017, 10, e1878. [CrossRef]

25. Gao, S.; Jia, J.J. Modeling suspended sediment distribution in continental shelf upwelling/downwelling settings. Geo Mar. Lett. 2002, 22, 218-226. [CrossRef]

26. Newbold, J.D.; Thomas, S.A.; Minshall, G.W.; Cushing, C.E.; Georgian, T. Deposition, benthic residence, and resuspension of fine organic particles in a mountain stream. Limnol. Oceanogr. 2005, 50, 1571-1580. [CrossRef]

27. Harvey, J.W.; Drummond, J.D.; Martin, R.L.; McPhillips, L.E.; Packman, A.I.; Jerolmack, D.J.; Stonedahl, S.H.; Aubeneau, A.F.; Sawyer, A.H.; Larsen, L.G.; et al. Hydrogeomorphology of the hyporheic zone: Stream solute and fine particle interactions with a dynamic streambed. J. Geophys. Res. Biogeosci. 2012, 117. [CrossRef]

28. Bombardelli, F.A.; Moreno, P.A. Exchange at the bed sediments-water column interface. In Fluid Mechanics of Environmental Interfaces, 2nd ed.; Gualtieri, C., Mihailovic, D.T., Eds.; CRC Press/Balkema: Leiden, The Netherlands, 2012; pp. 221-253. ISBN 978-0-415-62156-4.

29. Tupinambás, T.H.; Cortes, R.M.; Varandas, S.G.; Hughes, S.J.; França, J.S.; Callisto, M. Taxonomy, metrics or traits? Assessing macroinvertebrate community responses to daily flow peaking in a highly regulated Brazilian river system. Ecohydrology 2014, 7, 828-842. [CrossRef]

30. Wang, P.; Pozdniakov, S.P.; Vasilevskiy, P.Y. Estimating groundwater-ephemeral stream exchange in hyper-arid environments: Field experiments and numerical simulations. J. Hydrol. 2017, 555, 68-79. [CrossRef]

31. Kitheka, J.U.; Obiero, M.; Nthenge, P. River discharge, sediment transport and exchange in the Tana Estuary, Kenya. Estuar. Coast. Shelf Sci. 2005, 63, 455-468. [CrossRef]

32. Tronstad, L.M.; Tronstad, B.P.; Benke, A.C. Invertebrate responses to decreasing water levels in a subtropical river floodplain wetland. Wetlands 2005, 25, 583-593. [CrossRef]

33. Gautier, E.; Brunstein, D.; Vauchel, P. Temporal relations between meander deformation, water discharge and sediment fluxes in the floodplain of the Rio Beni (Bolivian Amazonia). Earth Surf. Proc. Landf. 2007, 32, 230-248. [CrossRef]

34. Gomi, T.; Kobayashi, S.; Negishi, J.N.; Imaizumi, F. Short-term responses of macroinvertebrate drift following experimental sediment flushing in a Japanese headwater channel. Landsc. Ecol. Eng. 2010, 6, 257-270. [CrossRef]

35. Jones, J.I.; Murphy, J.F.; Collins, A.L.; Sear, D.A.; Naden, P.S.; Armitage, P.D. The impact of fine sediment on macro-invertebrates. River Res. Appl. 2012, 28, 1055-1071. [CrossRef]

36. Fowler, R.T.; Scarsbrook, M.R. Influence of hydrologic exchange patterns on water chemistry and hyporheic invertebrate communities in three gravel-bed rivers. New Zealand J. Mar. Freshw. Res. 2002, 36, 471-482. [CrossRef]

37. Franken, R.J.M.; Storey, R.G.; Williams, D.D. Biological, chemical and physical characteristics of downwelling and upwelling zones in the hyporheic zone of a north-temperate stream. Hydrobiologia 2001, 444, 183-195. [CrossRef] 
38. Heip, C.H.R.; Herman, P.M.J.; Soetaert, K. Indices of diversity and evenness. Oceanis 1998, 24, 61-88.

39. Tupinambás, T.H.; Cortes, R.M.; Hughes, S.J.; Varandas, S.G.; Callisto, M. Macroinvertebrate responses to distinct hydrological patterns in a tropical regulated river. Ecohydrology 2016, 9, 460-471. [CrossRef]

40. Béjar, M.; Gibbins, C.N.; Vericat, D.; Batalla, R.J. Effects of suspended sediment transport on invertebrate drift. River Res. Appl. 2017, 33, 1655-1666. [CrossRef]

41. Xu, S.; Song, J.; Jiang, W.; Zhang, G.; Wen, M.; Zhang, J.; Xue, Y. Variability of Darcian Flux in the Hyporheic Zone at a Natural Channel Bend. Water 2017, 9, 170. [CrossRef]

42. Li, S.; Yang, W.; Wang, L.; Chen, K.; Xu, S.; Wang, B. Influences of environmental factors on macroinvertebrate assemblages: Differences between mountain and lowland ecoregions, Wei River, China. Environ. Monit. Assess. 2018, 190, 152. [CrossRef]

43. Lu, C.; Chen, S.; Zhang, Y.; Su, X.; Chen, G. Heat tracing to determine spatial patterns of hyporheic exchange across a river transect. Hydrogeol. J. 2017, 25, 1633-1646. [CrossRef]

44. Song, J.; Zhang, G.; Wang, W.; Liu, Q.; Jiang, W.; Guo, W.; Tang, B.; Bai, H.; Dou, X. Variability in the vertical hyporheic water exchange affected by hydraulic conductivity and river morphology at a natural confluent meander bend. Hydrol. Process. 2017, 31,3407-3420. [CrossRef]

45. Bredehoeft, J.D.; Papaopulos, I.S. Rates of vertical groundwater movement estimated from the Earth's thermal profile. Water Resour. Res. 1965, 1, 325-328. [CrossRef]

46. Boyle, J.M.; Saleem, Z.A. Determination of recharge rates using temperature-depth profiles in wells. Water Resour. Res. 1979, 15, 1616-1622. [CrossRef]

47. Arriaga, M.A.; Leap, D.I. Using solver to determine vertical groundwater velocities by temperature variations, Purdue University, Indiana, USA. Hydrogeol. J. 2006, 14, 253-263. [CrossRef]

48. Wang, W.; Song, J.; Zhang, G.; Liu, Q.; Guo, W.; Tang, B.; Cheng, D.; Zhang, Y. The influence of hyporheic upwelling fluxes on inorganic nitrogen concentrations in the pore water of the Weihe River. Ecol. Eng. 2018, 112, 105-115. [CrossRef]

49. Wang, L.; Jiang, W.; Song, J.; Dou, X.; Guo, H.; Xu, S.; Zhang, G.; Wen, M.; Long, Y.; Li, Q. Investigating spatial variability of vertical water fluxes through the streambed in distinctive stream morphologies using temperature and head data. Hydrogeol. J. 2017, 25, 1283-1299. [CrossRef]

50. Gualtieri, C.; Angeloudis, A.; Bombardelli, F.; Jha, S.; Stoesser, T. On the Values for the Turbulent Schmidt Number in Environmental Flows. Fluids 2017, 2, 17. [CrossRef]

51. García, M.H. Sediment transport and morphodynamics. In Sedimentation Engineering: Processes, Measurements, Modeling and Practice; García, M.H., Ed.; ASCE: Reston, VA, USA, 2008; pp. 21-163.

52. Julien, P.Y. River Mechanics; Cambridge University Press: Cambridge, UK, 2002; p. 434.

53. Chanson, H. Environmental Hydraulics of Open Channel Flows; Elsevier Butterworth-Heinemann: Oxford, UK, 2004; p. 483.

54. Ding, J.; Jiang, Y.; Fu, L.; Liu, Q.; Peng, Q.; Kang, M. Impacts of land use on surface water quality in a subtropical River Basin: A case study of the Dongjiang River Basin, Southeastern China. Water 2015, 7, 4427-4445. [CrossRef]

55. Li, W.; Wang, J.; Yang, S.; Zhang, P. Determining the existence of the fine sediment flocculation in the Three Gorges Reservoir. J. Hydraul. Eng. 2014, 141, 05014008. [CrossRef]

56. Haaland, S.E. Simple and explicit formulas for the friction factor in turbulent pipe flow. J. Fluids Eng. 1983, 105, 89-90. [CrossRef]

57. Whipple, K.X. 12.163 Course Notes, MIT Open Courseware. Available online: http: //ocw.mit.edu/NR/rdonlyres/Earth-Atmospheric--and-Planetary-Sciences/12-163Fall-2004/9D91F4427769-4CAE-853E213FCBD04081/0/3_flow_around_bends.pdf (accessed on 30 April 2019).

58. Stark, J.D.; Boothroyd, I.K.G.; Harding, J.S.; Maxted, J.R.; Scarsbrook, M.R. Protocols for sampling macroinvertebrates in wadeable streams; Cawthron Institute: Wellington, New Zealand, 2001; p. 57.

59. Luo, K.; Hu, X.; He, Q.; Wu, Z.; Cheng, H.; Hu, Z.; Mazumder, A. Impacts of rapid urbanization on the water quality and macroinvertebrate communities of streams: A case study in Liangjiang New Area, China. Sci. Total Environ. 2018, 621, 1601-1614. [CrossRef] [PubMed]

60. Thorp, J.H.; Covich, A.P. Ecology and Classification of North American Freshwater Invertebrates; Academic Press: San Diego, CA, USA, 2009.

61. Oscoz, J.; Galicia, D.; Miranda, R. Identification Guide of Freshwater Macroinvertebrates of Spain; Springer: Dordrecht, The Netherlands, 2011. 
62. Pielou, B.C. Ecological Diversity; John Wiley \& Sons: New York, NY, USA, 1975.

63. Shannon, C.E.; Weaver, W. The Mathematical Theory of Communication; University of Illinois Press: Urbana, IL, USA, 1949.

64. Margalef, R. Perspectives in Ecological Theory; University of Chicago Press: Chicago, IL, USA, 1968; p. 112.

65. Rabení, C.F.; Doisy, K.E.; Zweig, L.D. Stream invertebrate community functional responses to deposited sediment. Aquat. Sci. 2005, 67, 395-402. [CrossRef]

66. Harrison, A.B.; Slack, W.T.; Killgore, K.J. Feeding habitats of young-of-year River Sturgeon Scaphirhynchus spp. in the lower Mississippi River. Am. Midl. Nat. 2014, 171, 54-68. [CrossRef]

67. Sueyoshi, M.; Nakano, D.; Nakamura, F. The relative contributions of refugium types to the persistence of benthic invertebrates in a seasonal snowmelt flood. Freshw. Biol. 2014, 59, 257-271. [CrossRef]

68. Schmidt-Kloiber, A.; Nijboer, R.C. The effect of taxonomic resolution on the assessment of ecological water quality classes. Hydrobiologia 2004, 516, 269-283. [CrossRef]

69. Kang, J.; Koo, B.J.; Jeong, K.S.; Woo, H.J.; Seo, J.; Seo, H.S.; Kim, M.S.; Kwon, K. Insights into Macroinvertebrate burrowing Activity and Methane Flux in Tidal Flats. J. Coast. Res. 2018, 85, 681-685. [CrossRef]

70. Pang, C.H.D. Upwelling and sedimentation dynamics III: Coincidence of upwelling areas with mud patches in north hemisphere shelf seas. Chin. J. Oceanol. Limn. 2002, 20, 101-106.

71. Blettler, M.; Amsler, M.L.; Ezcurra de Drago, I.; Espinola, L.A.; Eberle, E.; Paira, A.; Best, J.L.; Parsons, D.R.; Drago, E.E. The impact of significant input of fine sediment on benthic fauna at tributary junctions: A case study of the Bermejo-Paraguay River confluence, Argentina. Ecohydrology 2015, 8, 340-352. [CrossRef]

72. Lou, J.; Guo, M.; Chen, M. Studies on the effect of environmental factors on growth of tubificidae. In Proceedings of the International Conference on Remote Sensing, Environment and Transportation Engineering (RSETE), Nanjing, China, 24-26 June 2011; IEEE: New York, NY, USA, 2011; pp. 4442-4445.

73. Mermillod-Blondin, F.; Rosenberg, R. Ecosystem engineering: The impact of bioturbation on biogeochemical processes in marine and freshwater benthic habitats. Aquat. Sci. 2006, 68, 434-442. [CrossRef]

74. Wang, G.; Li, J.; Sun, W.; Xue, B.; Yinglan, A.; Liu, T. Non-point source pollution risks in a drinking water protection zone based on remote sensing data embedded within a nutrient budget model. Water Res. 2019, 157, 238-246. [CrossRef]

75. Zhao, C.; Liu, C.; Zhao, J.; Xia, J.; Yu, Q.; Eamus, D. Zooplankton in highly regulated rivers: Changing with water environment. Ecol. Eng. 2013, 58, 323-334. [CrossRef]

76. Larsen, S.; Pace, G.; Ormerod, S.J. Experimental effects of sediment deposition on the structure and function of macroinvertebrate assemblages in temperate streams. River Res. Appl. 2011, 27, 257-267. [CrossRef]

77. Boulton, A.J.; Findlay, S.; Marmonier, P.; Stanley, E.H.; Valett, H.M. The functional significance of the hyporheic zone in streams and rivers. Ann. Rev. Ecol. Syst. 1998, 29, 59-81. [CrossRef]

78. Walker, R.R. Modelling Sediment Oxygen Demand in Lakes; McMaster University: Ham, ON, Canada, 1980.

79. Jacobsen, D. Low oxygen pressure as a driving factor for the altitudinal decline in taxon richness of stream macroinvertebrates. Oecologia 2008, 154, 795-807. [CrossRef]

80. Comer-Warner, S.; Romeijn, P.; Krause, S.; Hannah, D.M.; Gooddy, D. Temperature and organic matter controls on hyporheic greenhouse gas production. In AGU Fall Meeting Abstracts; AGU Publication: Washington, DC, USA, 2016.

81. Mehring, A.S.; Cook, P.L.; Evrard, V.; Grant, S.B.; Levin, L.A. Pollution-tolerant invertebrates enhance greenhouse gas flux in urban wetlands. Ecol. Appl. 2017, 27, 1852-1861. [CrossRef]

82. Kaplan, L.A.; Larson, R.A.; Bott, T.L. Patterns of dissolved organic carbon in transport 1. Limnol. Oceanogr. 1980, 25, 1034-1043. [CrossRef]

83. Corson-Rikert, H.A.; Wondzell, S.M.; Haggerty, R.; Santelmann, M.V. Carbon dynamics in the hyporheic zone of a headwater mountain stream in the Cascade Mountains, Oregon. Water Resour. Res. 2016, 52, 7556-7576. [CrossRef]

84. Lee, J.M.; Gan, J.Y.; Yule, C.M. The ecology of littoral zone Chironomidae in four artificial, urban, tropical Malaysian lakes. Urban Ecosyst. 2019, 22, 149-159. [CrossRef]

85. Tittensor, D.P. Ecology: Ecosystem vulnerability to ocean warming. Nature 2015, 528, 43. [CrossRef]

86. Humpesch, U.H. Life cycles and growth rates of Baetis spp. (Ephemeroptera: Baetidae) in the laboratory and in two stony streams in Austria. Freshw. Biol. 1979, 9, 467-479. [CrossRef] 
87. Anibas, C.; Fleckenstein, J.H.; Volze, N.; Buis, K.; Verhoeven, R.; Meire, P.; Batelaan, O. Transient or steady-state? Using vertical temperature profiles to quantify groundwater-surface water exchange. Hydrol. Process. 2009, 23, 2165-2177. [CrossRef]

88. $\mathrm{Hu}, \mathrm{D}$. Upwelling and sedimentation dynamics. Chin. J. Oceanol. Limn. 1984, 2, 12-19.

89. Gualtieri, C.; Mihailovic, D.T. Fluid Mechanics of Environmental Interfaces, 2nd ed.; CRC Press/Balkema: Leiden, The Netherlands, 2012; p. 498. ISBN 978-0-415-62156-4.

90. Liu, C.; Nepf, H. Sediment deposition within and around a finite patch of model vegetation over a range of channel velocity. Water Resour. Res. 2016, 52, 600-612. [CrossRef]

91. Chen, C.; Flores, A.N.; Aguayo, M. Exploring the Mitigation Potentials of Geophysical features on the Subsurface Flow Dominated by the Surface Hydrometeorological Conditions. In AGU Fall Meeting Abstracts; AGU Publication: Washington, DC, USA, 2018.

92. White, J.C.; Hannah, D.M.; House, A.; Beatson, S.J.; Martin, A.; Wood, P.J. Macroinvertebrate responses to flow and stream temperature variability across regulated and non-regulated rivers. Ecohydrology 2017, 10, e1773. [CrossRef]

93. Heffernan, J.B.; Sponseller, R.A.; Fisher, S.G. Consequences of a biogeomorphic regime shift for the hyporheic zone of a Sonoran Desert stream. Freshw. Biol. 2008, 5, 1954-1968. [CrossRef]

94. Bellamy, A.R.; Bauer, J.E.; Grottoli, A.G. Contributions of autochthonous, allochthonous, and aged carbon and organic matter to macroinvertebrate nutrition in the Susquehanna River basin. Freshw. Sci. 2019, 38, 616-628. [CrossRef]

95. Kondolf, G.M. Assessing salmonid spawning gravel quality. Trans. Am. Fish. Soc. 2000, 129, $262-281$. [CrossRef]

96. Acornley, R.M. Water temperatures within spawning beds in two chalk streams and implications for salmonid egg development. Hydrol. Process. 1999, 13, 439-446. [CrossRef]

(C) 2020 by the authors. Licensee MDPI, Basel, Switzerland. This article is an open access article distributed under the terms and conditions of the Creative Commons Attribution (CC BY) license (http://creativecommons.org/licenses/by/4.0/). 